УДК 338.246.2:336.02

DOI: https://doi.org/10.26642/jen-2020-1(91)-99-103

В.В. Войтенко, аспірант

Міжрегіональна академія управління персоналом

\title{
Фінансовий контроль як категорія фінансових відносин у системі державного управління
}

\author{
(Представлено: д.держ.упр., проф. Драган I.О.)
}

\begin{abstract}
Визначено, щзо, по-перше, фінансовий контроль має на увазі обов'язкову наявність відносин підлеглості та правила, виконання яких необхідно контролювати незалежно від сфери фінансових відносин (державні фінансові відносини, приватні фінансові відносини, фінанси домогосподарств тощо); по-друге, фінанси як економічна категорія в межах виконання своїх функцій передбачають створення правил, які регулювали б процеси формування, розподілу і використання фінансових ресурсів, а також визначали б можливості впливу на поведінку господарюючих суб'єктів з боку власника цих ресурсів. Оскільки ц̧і правила не мають об 'єктивного характеру і створюються людиною, дотримання їх необхідно контролювати. Їх виконавці мають можливість не виконувати ичі правила, змінювати їх для отримання своєї вигоди тощяо.

Зазначено, щзо фінансовий контроль - це багатогранна і складна фінансова категорія, сутність якої не можна обмежувати тільки практичною діяльністю або інформаційною системою. Вона пронизує всі аспекти фінансових відносин. Можуть змінюватися мета, завдання і методи здійснення фінансового контролю залежно від волі власників фінансових ресурсів, але сутність та функиіі фінансового контролю залишаються незмінними. Тому фінансовий контроль як фінансову категорію необхідно розглядати через сукупність характеристик, які мають розкривати все різноманіття його сутності, всебічно відбивати і комплексно охоплювати всі сторони його прояву.

Обгрунтовано, що сутність фінансового контролю як категорії фінансових відносин у системі державного управління розкривається через сукупність його характеристик, щуо представляють фінансовий контроль як область наукових $і$ спеціальних знань, як елемент системи управління, як особливий вид практичної діяльності та як інформаційну систему, яка використовується з метою управління.
\end{abstract}

Ключові слова: державне управління; контроль; фінанси; фінансова безпека; фінансовий контроль; фінансові відносини.

Постановка проблеми. Економічні перетворення в країні, соціальні зрушення, кризові явища в економіці, поширення корупції в усіх ешелонах влади, нові соціальні проекти, затверджені національні програми вимагають кардинального перегляду i вдосконалення системи державного управління. Виниклі перед суспільством і країною проблеми вимагають нових неординарних підходів. Заходи уряду і керівництва країни не дали належного ефекту і результату. Це призводить до того, що постає питання про вивчення, аналіз та перегляд управлінських функцій держави, зокрема контрольних.

За останній час істотно змінилися як об'єкти, так і суб'єкти фінансового контролю. Масштаби, характеристики, методи і форми підготовки та здійснення фінансових зловживань мають інші параметри. Фінансові порушення, що допускаються представниками влади, як правило, мають навмисний характер, що межує 3 кримінальною відповідальністю. Порушення принципів законності, ефективності та економії у витрачанні державних ресурсів виражається матеріальною шкодою, яка обчислюється у млрд грн, тим самим, здійснюючи економічну загрозу для країни.

Питання організації фінансового контролю набувають головного значення при організації боротьби 3 корупцією в органах виконавчої влади. Негативний досвід здійснення функцій державного управління без відповідного фінансового контролю в економіці відчутний до теперішнього часу.

Аналіз останніх досліджень і публікацій. Проблеми фінансового контролю як теоретичного, так i практичного аспектів, опубліковані в працях таких вчених, як: О.Д. Василик, К.В. Павлюк, Л.В. Гуцаленко, В.А. Дерій, М.М. Коцупатрий, І.М. Іванова, О.П. Кириленко, О.А. Шевчук та інших. Аналіз попередніх досліджень та публікацій цієї проблематики свідчить про те, що авторами досліджувалися лише окремі аспекти.

Постановка завдання. Метою статті $\epsilon$ обгрунтування сутності фінансового контролю як категорії фінансових відносин у системі державного управління.

Викладення основного матеріалу. Фінансовий контроль $\epsilon$, на нашу думку, найбільш важливим i значущим у системі державного управління. За допомогою фінансового контролю держава має можливість попередити або стримати штучно насаджувані «перепони» бюрократичним апаратом влади. Матеріали i результати контрольних заходів можуть бути основою для органів законодавчої влади у виданні нових нормативних документів, або внесенні доповнень і коригувань у раніше прийняті. 
Відмінність фінансового контролю полягає в тому, що він має всеосяжну особливість, є універсальним за своїм змістом і застосуванням в усіх сферах державного управління, громадського виробництва, соціального устрою країни, включно з інтересами суспільства.

Розуміння сутності фінансового контролю в сучасних уявленнях про нього в основному зводиться тільки до формулювання визначення фінансового контролю і до спроб формулювання цілей та завдань, а також функцій фінансового контролю. $С$ загальновизнані постулати, які ряд авторів зараховує до суті фінансового контролю. До таких постулатів належать, наприклад, формулювання контрольної функції фінансів або положення про те, що фінансовий контроль $є$ невід'ємним елементом системи державного управління. Такий підхід до розуміння сутності контролю взагалі та фінансового контролю зокрема призводить, 3 одного боку, до обмеженого розуміння сутності фінансового контролю, як правило, в результаті розгляду тільки однісї вибраної характеристики, а з другого - до вільного використання фінансового контролю на практиці через нерозуміння його сутності в цілому.

Розглянемо поняття «фінансовий контроль» як невід’ємну частину фінансових відносин, що реально має місце бути незалежно від волі суб'єктів, які їх здійснюють, тобто як фінансову категорію.

Виконання фінансами своїх функцій в межах економічних та грошових відносин підпорядковується тим правилам, які створює власник фінансових ресурсів, і не залежить від товарно-грошових, кредитних або будьяких інших економічних відносин. При цьому фінансові відносини через розподільну та регулюючу функції фінансів здатні впливати на будь-які інші відносини в межах громадських, а тим більше економічних. Оскільки правила фінансової діяльності створює власник фінансових ресурсів у межах управління ними, то вони не мають об'єктивного характеру і можуть не виконуватися і навіть змінюватися тими, для яких призначені, тобто виконавцями цих правил. Тому їх виконання необхідно контролювати в межах фінансового управління 3 боку власника ресурсів. Саме тут і проявляється контрольна функція фінансів.

Василик О.Д. розширив наведене вище визначення та зазначив, що «фінансовий контроль за своєю економічною суттю - це функція управління, яка містить сукупність спостережень, перевірок за діяльністю об’єкта управління 3 метою оцінки обгрунтованості й ефективності прийняття рішень і результатів їх виконання» [4]. Автор слушно зауважив «методи, за допомогою яких здійснюється управління, однак не всі, залишаючи поза увагою, зокрема аналіз, обстеження та інші» [4].

Юрій С.І., Стоян В.І., Мац М.Й. стверджують, що «фінансовий контроль є важливим елементом системи управління фінансами; він включає контроль за дотриманням фінансово-економічного законодавства у процесі формування і використання грошових фондів, оцінку ефективності фінансово-господарських операцій i доцільність здійснених видатків» [12].

Мандрица В.М. доводить, що «фінансовий контроль - сукупність дій і операцій щодо перевірки фінансових та пов'язаних з ними питань діяльності суб'єктів господарювання й управління в галузі освіти, розподілу та використання грошових фондів держави й суб'єктів місцевого самоврядування із застосуванням специфічних форм і методів його організації» [8].

Кириленко О.П. визначає фінансовий контроль як «контроль за законністю і доцільністю дій в галузі освіти, розподілу і виконання грошових фондів держави і муніципальних утворень, з метою ефективного соціальноекономічного розвитку країни та її регіонів» [7].

Романенко О. наголошує, що «фінансовий контроль можна розглядати в двох аспектах. Він завжди супроводжує людську діяльність, є важливою функцією державного управління, бо слугує цілям перевірки правильності дій. Управління неможливе без отримання інформації про виконання правових приписів, і таку інформацію надає контроль. Його основна мета у цьому випадку з'ясувати, чи всі можливі засоби були використані для виконання управлінського рішення, чи всі умови створені для його реалізації, чи $є$ помилки $і$ недоліки, та які шляхи їх усунення» [10].

Родіонова В.М., Шлейников B.I., зазначають, що «фінансовий контроль є процесом, в результаті якого аналізується діяльність суб'єктів господарювання та органів влади з метою перевірки стану використання та наявності резервів зростання фінансових ресурсів, ефективності їх використання, а також перевірки правильності складання і виконання бюджетів, ведення обліку та дотримання законодавства» [9].

На думку Т.О. Башкатової, фінансовий контроль «є невід'ємним елементом управління фінансовими та грошовими потоками на макро-, та мікрорівні з метою забезпечення доцільності та ефективності фінансових операцій» [1]. Однак у той самий час вчена стверджує, що «фінансовий контроль являє собою діяльність контролюючих органів за дотриманням фінансового законодавства та фінансової дисципліни» [1].

Бурцев В.В. вважає, що «фінансовий контроль - це особлива функція фінансів, яка повинна розкривати відхилення від прийнятих стандартів управління фінансами, а при виявленні таких відхилень - своєчасно приймати відповідні коригувальні та запобіжні заходи» [2]. «Фінансовий контроль пронизує всі сфери відтворення, а також супроводжує рух грошових ресурсів, а також це об'єктивно необхідний доданок будьякого господарського механізму» [2].

Отже, фінансовий контроль можна охарактеризувати за трьома напрямами:

- по-перше, як «функцію управління фінансами, де, з одного боку, він є засобом поєднання функцій фінансового планування і прогнозування, фінансового обліку та статистики, 3 другого - передумовою здійснення функцій фінансового аналізу та регулювання» [3]; 
- по-друге, як «комплексну і цілеспрямовану фінансово-правову діяльність органів фінансового контролю або їх підрозділів чи представників, а також осіб, уповноважених здійснювати контроль, що базується на положеннях актів чинного законодавства. Фінансовий контроль передбачає перевірку господарських i фінансових операцій щодо їхньої достовірності, законності, доцільності й ефективності» [5];

- по-третє, як «регламентовану чинним законодавством і установчими документами діяльність державних, регіональних, галузевих органів, громадськості, саморегульованих організацій, суб'єктів господарювання 3 контролю за правильністю фінансового планування, обгрунтованістю, повнотою і своєчасністю надходжень до фондів грошових коштів, а також законністю й ефективністю їх використання» [11].

У зв’язку зі сказаним вище, можна стверджувати, що фінансовий контроль традиційно розглядають як вид практичної діяльності спеціалізованих підрозділів підприємства (якщо це внутрішній фінансовий контроль або аудит), державних органів фінансового контролю (якщо ведеться мова про державний фінансовий контроль) або аудиторських фірм. Ця сторона сутності фінансового контролю найбільш досліджена, тому що вона яскраво проявляється у фінансовій діяльності економічних суб'єктів. Крім того, дуже часто фінансовий контроль розглядається як функція системи управління.

Можна зробити висновок, що сучасна наукова думка до визначення сутності фінансового контролю дещо однобічна, намагається розкрити прояв його сутності через розгляд однієї вибраної характеристики або функції.

Існує ще один підхід до визначення сутності фінансового контролю. Він зводиться до розгляду фінансового контролю як категорії фінансових відносин. Так І.М. Іванова вважає, що фінансовий контроль $є$ надзвичайно багатогранною, складною і комплексною економічною категорією [6]. Цей висновок підтверджується i зазначеним вище різноманіттям думок на сутність фінансового контролю.

Грунтуючись на результатах дослідження сучасних поглядів на сутність фінансового контролю, можна зробити такі висновки:

- по-перше, фінансовий контроль має на увазі обов’язкову наявність відносин підлеглості та правила, виконання якого необхідно контролювати незалежно від сфери фінансових відносин (державні фінансові відносини, приватні фінансові відносини, фінанси домогосподарств тощо);

- по-друге, фінанси як економічна категорія в межах виконання своїх функцій передбачають створення правил, які регулювали б процеси формування, розподілу і використання фінансових ресурсів, а також визначали б можливості впливу на поведінку господарюючих суб'єктів з боку власника даних ресурсів.

Оскільки ці правила не мають об'єктивного характеру і створюються людиною, дотримання їх необхідно контролювати, їх виконавці мають можливість не виконувати дані правила, змінювати їх для отримання своєї вигоди тощо.

3 огляду на сказане вище, можна стверджувати, що фінансовий контроль - це багатогранна і складна фінансова категорія, сутність якої не можна обмежувати тільки практичною діяльністю або інформаційною системою. Вона пронизує всі аспекти фінансових відносин. Можуть змінюватися мета, завдання і методи здійснення фінансового контролю залежно від волі власників фінансових ресурсів, але сутність та функції фінансового контролю залишаються незмінними. Тому фінансовий контроль як фінансову категорію необхідно розглядати через сукупність характеристик, які мають розкривати все різноманіття його сутності, всебічно відбивати і комплексно охоплювати всі сторони його прояву. Ми пропонуємо використовувати такі характеристики сутності фінансового контролю, як:

- область спеціальних і наукових знань;

- елемент системи управління;

- особливий вид практичної діяльності;

- інформаційна система, яка використовується з метою управління.

Кожна 3 названих сутнісних характеристик має свої особливості, відмітні ознаки, при цьому вони нерозривно пов'язані і взаємно впливають одна на одну.

Без наукових і спеціальних знань неможливо визначити і виробити методологічні підходи та прийоми 3 організації фінансового контролю як на мікро-, так і на макроекономічному рівнях. Не розуміючи його ролі $\mathrm{i}$ місця у структурі управління, не вміючи зробити правильний вибір стратегії й тактики його здійснення, можна погіршити фінансовий стан підприємства або навіть перешкоджати виконанню основної місії господарюючого суб'єкта. У процесі практичної діяльності користувачами інформації фінансового контролю може бути затребувана не тільки інформація, що стосується результатів діяльності (звіти, акти, аудиторський висновок тощо), але й інформація, яка $є$ «продуктом переробки» в інформаційній системі фінансового контролю. Результати практичної діяльності переробляються в інформаційній системі та істотно впливають на наукову складову сутності фінансового контролю і його характеристику як елемента системи управління, змушуючи власника або найманого керуючого при необхідності вносити корективи в них. Взаємозв'язок і взаємний вплив сутнісних характеристик фінансового контролю показані на рисунку 1. 


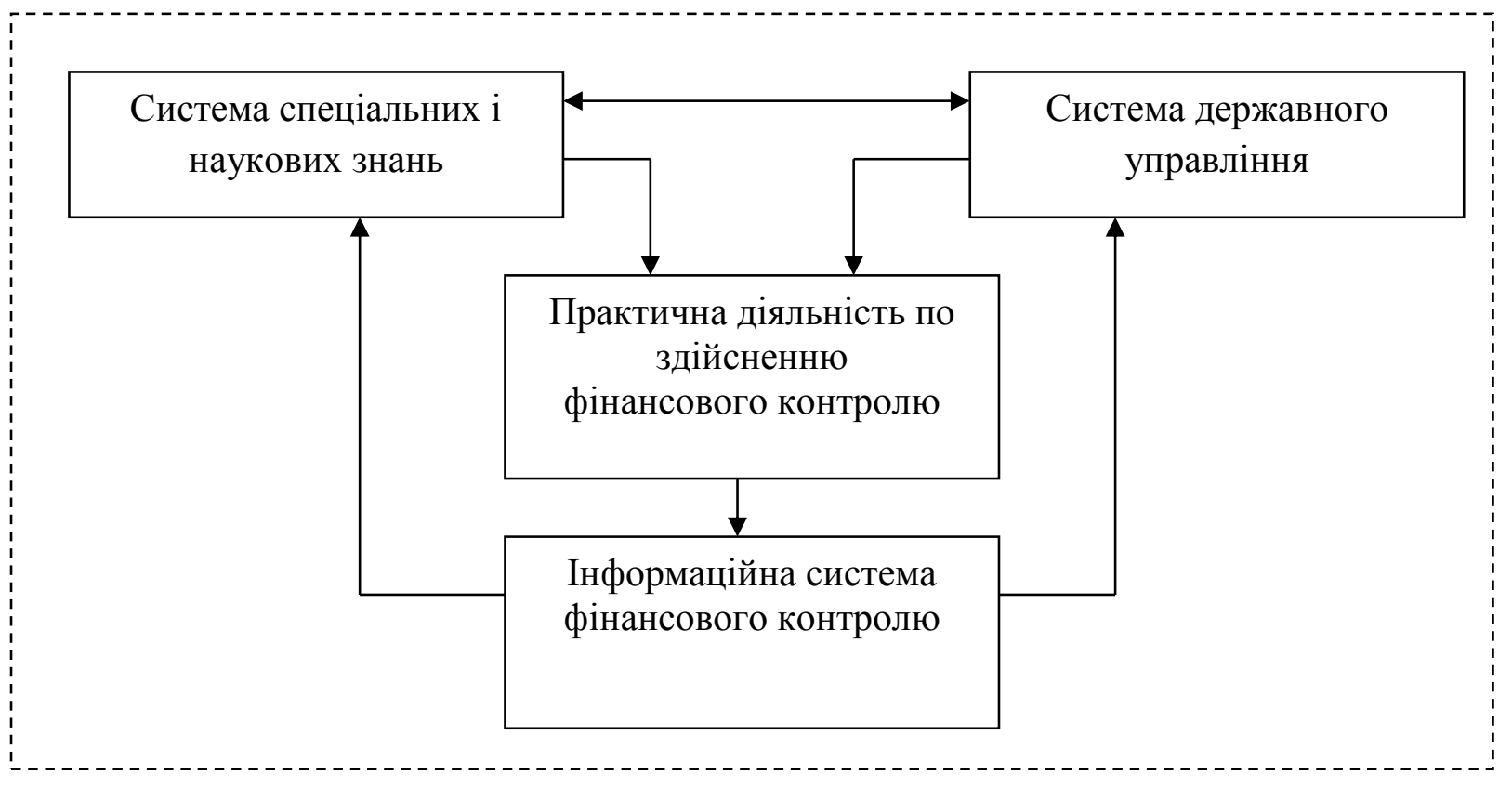

Рис. 1. Сутність фінансового контролю через взаємодію його характеристик

Розглянемо докладніше названі характеристики, що відображають сутність фінансового контролю.

Як область спеціальних і наукових знань фінансовий контроль виражений системою ідей, що пояснюють досліджувану область і формують іï теоретичні основи. Як правило, фінансовий контроль розглядають як функцію фінансів і через призму різних фінансових відносин. Крім того, саме в межах цієї характеристики фінансовий контроль представляють як категорію фінансів. При цьому мається на увазі, що людина (юридична особа, держава), яка вступила у фінансові відносини з іншими людьми (юридичними особами, державою), змушена постійно відстежувати цілісність фінансових ресурсів, які вона їм передала у тимчасове користування, або в управління, або на зберігання, правильність їх використання та цільове призначення. Отже, з появою нових видів і форм фінансових відносин необхідно пристосовувати існуючі підходи до контролю або винаходити нові.

Наприклад, поява все більшого поширення електронних грошей дозволяє обходити виставлені контролем бар'єри, ефективні для паперових грошей. Так, щоб провести будь-яку банківську операцію, сьогодні вже не обов'язкові особиста присутність клієнта в банку і звірка його підпису зі зразком. А доступність електронних засобів комунікацій дозволяє шахраям використовувати цю прогалину в контролі у своїх цілях. Тому зараз все більшого значення набувають засоби і методи електронного захисту власних капіталів.

Висновки. Бурхливий розвиток теорій управління змушує фінансовий контроль знаходити все більш дієві та ефективні види і форми виконання завдань, що стоять перед ним. Управління та контроль роблять взаємний вплив на розвиток один одного. Розробляючи ті чи інші структури і форми управління, вчені одним із найважливіших завдань ставлять вирішення проблеми ефективності контролю, тобто найбільший результат при мінімумі витрат. У вирішенні цих проблем їм допомагає подальший розвиток видів і форм фінансового контролю.

За підсумками розгляду характеристик сутності фінансового контролю можна сформулювати його загальне визначення. Ми вважаємо, що сутність фінансового контролю як категорії фінансових відносин у системі державного управління розкривається через сукупність його характеристик, що становлять фінансовий контроль як область наукових і спеціальних знань, як елемент системи управління, як особливий вид практичної діяльності і як інформаційну систему, яка використовується з метою управління.

\section{Список використаної літератури:}

1. Башкатова Т.А. Сущность и функции финансового контроля / Т.А. Башкатова ; под ред. проф. Л.А. Дробозиной // Финансы. - М. : ЮНИТИ, 2001. - 527 с.

2. Буриев В.В. Организация системы государственного финансового контроля: теория и практика / В.В. Бурцев. - М. : Дашков и К, 2002. - 496 с.

3. Василик О.Д. Державні фінанси України : підруч. / О.Д. Василик, К.В. Павлюк. - Київ : НІОС, 2002. - 608 с.

4. Василик О.Д. Теорія фінансів : підруч. / О.Д. Василик-К. : НІОС, 2000. - 416 с.

5. Гуцаленко Л.В. Державний фінансовий контроль : навч. посіб. / Л.В. Гуцаленко В.А. Дерій, М.М. Коиупатрий. - К. : ЦУЛ, 2009. - 424 с.

6. Іванова I.M. Державний фінансовий контроль: парадигми розвитку : монографія / I.M. Іванова. - К. : Академвидав, 2010. - 168 c. 
7. Кириленко О.П. Фінанси (теорія та вітчизняна практика) : навч. посіб. / О.П. Кириленко. - Тернопіль : Астон, 2002. $-212 \mathrm{c}$.

8. Мандрица В.М. Финансовое право / В.М Мандрица. - Ростов-на-Дону : Феникс, 1999. - 448 с.

9. Родионова В.М. Финансовый контроль : учебник / В.М. Родионова, В.И. Шлейников. - М. : ИД ФКБ-ПРЕСС, 2002. $-320 \mathrm{c}$.

10. Романенко О. Фінанси : підручник / О.Романенко. - К. : Центр навчальної літератури, 2006. -312 с.

11. Шевчук О.А. Державний фінансовий контроль в Україні: теорія, методологія, практика : автореф. дис. д-ра екон. наук : 08.00.08 / O.А. Шевчук. - Київ, 2014. -42 с.

12. Юрій С.I. Казначейська система : підручник / C.I. Юрій, В.І. Стоян, М.Й. Маu. - Тернопіль : Карт-бланш, 2002. $590 \mathrm{c}$.

\section{References:}

1. Bashkatova, T.A. (2001), «Sushhnost' i funkcii finansovogo kontrolja», Finansy, in Drobozina, L.A. (ed.), JuNITI, Moskva, 527 p.

2. Burcev, V.V. (2002), Organizacija sistemy gosudarstvennogo finansovogo kontrolja: teorija i praktika, Dashkov i K, Moskva, $496 \mathrm{p}$.

3. Vasylyk, O.D. and Pavljuk, K.V. (2000), Derzhavni finansy Ukrai'ny, pidruch, NIOS, Kyi'v, 608 p.

4. Vasylyk, O.D. (2000), Teorija finansiv, pidruch, NIOS, Kyi'v, 416 p.

5. Gucalenko, L.V., Derij, V.A. and Kocupatryj, M.M. (2009), Derzhavnyj finansovyj kontrol' , navch. posib, Centr uchbovoi' literatury, Kyi'v, 424 p.

6. Ivanova, I.M. (2010), Derzhavnyj finansovyj kontrol': paradygmy rozvytku, monografija, Akademvydav, Kyi'v, 168 p.

7. Kyrylenko, O.P. (2002), Finansy (teorija ta vitchyznjana praktyka), navch. posib, Aston, Ternopil', 212 p.

8. Mandrica, V.M. (1999), Finansovoe pravo, Feniks, Rostov-na-Donu, 448 p.

9. Rodionova, V.M. and Shlejnikov, V.I. (2002), Finansovyj kontrol', uchebnik, ID FKB-PRESS, Moskva, 320 p.

10. Romanenko, O. (2006), Finansy, pidruchnyk, Centr navchal'noi' literatury, Kyi'v, 312 p.

11. Shevchuk, O.A. (2014), Derzhavnyj finansovyj kontrol'v Ukrai'ni: teorija, metodologija, praktyka, Abstract of Diss. of. d.e.n., spec. 08.00.08, Kyi'v, 42 p.

12. Jurij, S.I., Stojan, V.I. and Mac, M.J. (2002), Kaznachejs'ka systema, pidruchnyk, Kart-blansh, Ternopil', 590 p.

Войтенко Володимир Валентинович - аспірант Міжрегіональної академії управління персоналом.

Наукові інтереси:

- механізми державного управління;

- місцеві бюджети;

- фінансовий контроль.

https://orcid.org/0000-0003-4315-7115.

Стаття надійшла до редакції 06.02.2020. 